\title{
Economic impossibility in Turkish contract law from the perspective of law and economics
}

\author{
Hüseyin Can Aksoy • Hans-Bernd Schäfer
}

Published online: 9 July 2010

(C) Springer Science+Business Media, LLC 2010

\begin{abstract}
We argue that the proposed introduction of the doctrine of economic impossibility in Article 137 of the reform draft of the Turkish Code of Obligations is in line with economic considerations and facilitates business transactions. This new rule gives courts the explicit power to terminate a contract and relieve the party, which owes specific performance of its obligation, without imposing any duty to pay expectation damages to the other party. We argue that a court's decision to terminate a contract under economic impossibility should be based on three tests. First, a low-probability-event occurs between contract formation and performance. Second, this event causes an excessive increase in the costs of specific performance. Third, the concept of an excessive increase should take into due consideration the other party's interest in specific performance. The reform draft includes explicitly the first two tests, but not the third test. We also show under which conditions an excessive performance difficulty should not lead to termination of the contract but rather to an adjustment of the agreed price. We argue that the rule of economic impossibility, if diligently adjudicated, saves the parties transactions costs in
\end{abstract}

The authors thank Prof. Claus Ott for helpful comments and also Soehnke Haeseler for line editing and helpful comments on an earlier draft. The usual disclaimer applies.

\footnotetext{
H. C. Aksoy

Çakmak Law Office, Ankara, Turkey

e-mail: hcanaksoy@gmail.com
}

H. C. Aksoy

Martin-Luther-Universität Halle-Wittenberg, Halle-Wittenberg, Germany

H.-B. Schäfer ( $₫)$

Bucerius Law School, Hamburg, Germany

e-mail: hans-bernd.schaefer@law-school.de; schaefer@uni-hamburg.de

H.-B. Schäfer

Bilkent University Faculty of Law, Bilkent, Ankara, Turkey 
comparison to a rule under which the law insists on specific performance or damage payments. We also argue that a specific rule of economic impossibility leads to better and more business-oriented solutions to the underlying problems than the alternative, which is to solve such problems under the broad and unspecific cover of the "good faith" or the "Clausula Rebus Sic Stantibus" doctrine.

Keywords Contract law - Impossibility - Excessive performance difficulty · Impracticability

\section{JEL Classification $\mathrm{K}$ (Law and Economics)}

\section{Introduction}

Two cases illustrate the problem. (1) A shipping company agrees to ship a water pump from Istanbul to Mumbai for a fixed charge. A war in the Middle East leads to the closing of the Suez Canal. Freight costs from Istanbul to Mumbai rise to an unexpectedly high level as the ship must take the route around Africa. ${ }^{1}$ (2) A business person in Istanbul wants to run one of his restaurants as a "nostalgic restaurant". For this purpose, he buys furniture of a particular brand for the price of TL 20,000, by choosing from the sales catalogue of an antiques shop. At the time of the contract, the buyer has more than one sample of each selected furniture in his storage, which were produced around the year 1900 by a then well known French furniture corporation. However, before the seller sorts the goods to be delivered, a fire destroys all samples of half of the furniture. The buyer insists on performance and argues that he has bought furniture of a particular brand and that all the missing items are still available on secondary markets and auctions around the world. The seller argues correctly that even though this is true, he would have to incur costs (prices on the secondary market, transportation costs, customs duties, and transactions costs) of TL 400,000 to collect and deliver the missing items. Therefore, he denies performance.

In an early article on the problem, Trimarchi ${ }^{2}$ wrote "Most of the papers which discuss this subject from an economic point of view deal with the issue of "impossibility" in the broadest terms, placing "commercial impossibility" (or "impracticability"), "physical impossibility" and "frustration of purpose" side by side".

When we approach these cases from an economic perspective, we make three important observations. First, both contracts, which ex-ante (at the time of their formation) led to an expected gain for both parties, a "win-win" constellation results in a loss of one party, if the legal order preserves the profit of the other party by insisting on specific performance at the stipulated price. Therefore performance would lead to a "win-loose" constellation ex-post.

\footnotetext{
${ }^{1}$ It is questionable whether this case could today be headed under economic impossibility, given the frequency of violence in the Middle East. But in 1956 it could be regarded as a very exceptional and unexpected event.

2 Trimarchi (1991).
} 
Second, even if the idea of a "nostalgia restaurant" might be a great business idea, the additional costs of the specific performance, caused by the fire, wouldbeyond reasonable doubt—be much higher than the profits of the restaurant owner. Not only would one party loose by the specific performance, but her losses would also outweigh the benefits of the other party, especially if one considers that the planned restaurant can also be run with a different brand of antique furniture. The whole rationale of a contract as an instrument to generate gains would break down.

Finally, the third and crucial economic observation is that in this particular case it is obvious for a third party like a judge to see such change. We shall argue that the latter observation should lead to termination of the contract and free both parties from all obligations. ${ }^{3}$

However, the second and third observations do not hold for the first case, which therefore has a structure different from the second case. We shall argue that in this case courts should not terminate the contract, but adjust the price and give the other party the right to opt out of the contract.

Many legal orders provide a rule of economic impossibility or economic impracticability (see, for example, US Contract Law). ${ }^{4}$ This rule allows the party, which owes specific performance to terminate the contract without paying damage compensation. Similarly, German courts have developed the concept of economic impossibility (wirtschaftliche Unmöglichkeit), which allows denying specific performance. In the course of a major reform, this rule was explicitly incorporated into the Civil Code in 2002 (Section 275, 2 BGB). What is the rationale for this? Why does the law allow denying performance and consequently violating the principle of "Pacta Sunt Servanda" even though performance is possible, albeit at a very high cost? We tackle this problem from an economic point of view, starting with some illustrative cases from Turkish Law and introducing the Turkish doctrine of economic impossibility. We proceed by the literature review on the issue and briefly explain the two groups of approaches in the legal doctrine to the cases of impossibility. In addition, we show why specific performance should not take place if circumstances that threaten to annihilate or even reverse the surplus from the contract arise after contract formation. Moreover, we show that under ideal conditions, both the rule of expectation damages for breach of contract and the rule of specific performance give incentives to terminate the contract if the total surplus from it becomes negative between contract formation and performance. We show that these two rules provide a mechanism for the parties to breach a contract if and only if rising costs of performance after contract formation make the joint surplus from the contract negative. We then show that in exceptional cases of economic impossibility parties can save costs if the party, which owes specific performance, is allowed to deny performance without incurring any legal consequences such as paying damage compensation.

\footnotetext{
3 This consequence requires that the cause for an excessive increase of the performance costs was not negligently set by the party, which owes the specific performance.

${ }^{4}$ Eisenberg (2009), Smythe (2003-2004), Skyes (1990).
} 
1.1 Economic impossibility in Turkish law

\subsubsection{Some illustrative cases from Turkish law}

1.1.1.1 Case 1: long term rent agreement The plaintiff rented the defendant's real estate for 10 years at a monthly rent of $\$ 5,500$. However, after the economic crisis in 2001 , the plaintiff argued that due to a $75 \%$ shift in the exchange rate, the balance of benefits between the parties had changed in such a way that performance of the contract was intolerable for him. Accordingly, he demanded that either the exchange rate be fixed for the purpose of the contract at TL 679.692 or that the rent be adjusted to $\$ 3,038$. $^{5}$

1.1.1.2 Case 2: mortgage credit In 2000, when the Deutschmark was worth TL $3,20,000$, the plaintiff took a foreign exchange housing loan of 35,000 DM from the defendant, which was to be repaid in 36 monthly installments. However, due to the economic crisis and devaluation, the DM appreciated to TL 5,00,000 and the plaintiff argued that as a retired civil servant, it was impossible for him to perform the contract and he demanded that, for the purpose of the contract, the exchange rate be fixed at TL $3,20,000{ }^{6}$

1.1.1.3 Case 3: retirement income contract In 1981, the plaintiff signed a retirement income contract with the defendant bank and paid a total of DM 12.600 over the course of 7 years. Accordingly, starting in 1988, the defendant paid a monthly income of TL 270.000 to the defendant. However, in 1999, the plaintiff argued that due to the high amount of inflation in the country, the balance of interests of the contract was damaged and he asked for termination of the contract. ${ }^{7}$

\subsubsection{Economic impossibility in Turkish legal doctrine}

The current Turkish Code of Obligations lacks any specific rule applicable to all cases of economic impossibility. However, in the doctrine the prevailing opinion is that economic impossibility, which causes an excessive increase in the cost of performance, is not technically an impossibility that can cancel the parties' obligations from the contract. ${ }^{8}$ Accordingly, as accepted both in the doctrine and by the Turkish Court of Cassation (Yargitay), the principle of good faith should be taken into consideration in case of an excessive performance difficulty. Furthermore, since the basis of the contract has collapsed, either the parties' contractual

\footnotetext{
5 See Yarg. 11. HD, 13.12.2001 T., E.2001/11526 K.2001/11752.

${ }^{6}$ See Yarg. 13. HD, 9.06.2005 T., E.2005/1874 K.2005/9749.

7 See Yarg. 11. HD, 25.1.2002 T., E.2001/7365 K.2002/477.

8 In this vein, see Eren (2008, p. 997), Kaplan (2007, p. 139), Tunçomağ (1967), Gürsoy (1950, p. 27), Erzurumluoğlu (1970, p. 60). According to Serozan, the line between the concepts of "subjective impossibility" and "excessive performance difficulty" is quite indistinct. However, the author argues that it would be more appropriate not to handle cases of economic impossibility with the technical institution of impossibility because solutions brought to excessive performance difficulty are much more flexible than the mechanical solutions brought to the cases of impossibility. Serozan (2006, p. 168).
} 
obligations should be adapted to the new conditions or the contract should be terminated, so that the debtor can be partially or completely be relieved of his obligations. ${ }^{9}$

According to Erzurumluoğlu, accepting excessive performance difficulty as a type of impossibility constitutes a contradiction in terms because, by definition, the concept of impossibility refers to a certainty. ${ }^{10}$ Therefore, if excessive performance difficulty is accepted as impossibility, this means that what is logically possible is deemed impossible. ${ }^{11}$ Similarly, Tunçomağ argues that the concept of "excessive performance difficulty" is a very clear term and clearly distinct from the term "impossibility". As a matter of fact, in case of impossibility, overcoming the obstacle to perform is not humanly possible, whereas in case of excessive performance difficulty, such an obstacle can be overcome, albeit at unreasonable costs. ${ }^{12}$

Another important reason why economic impossibility is not accepted as impossibility in Turkey in its technical meaning rests in its results. German courts created the concept of "economic impossibility" as a solution to cases in which the character of performance has changed completely due to the increase in cost and price. However, the legal result of this acceptance was that such contracts could not be sustained, since in cases of impossibility the contractual obligation would directly end. ${ }^{13}$ Therefore, if excessive performance difficulty is accepted as a type of impossibility, this will result in excessive protection of the debtor against the creditor. $^{14}$

In its various decisions, the Turkish Court of Cassation has also explicitly stated that an excessive performance difficulty is not technically an impossibility that cancels the parties' obligations. For instance, in one of its decisions, the court rejected the claims of a seller who argued that after the economic crisis and devaluation in the country, the extreme increase in the price of the goods subject to the contract, made it impossible for him to perform. The court emphasized that in case of impossibility the obligation automatically ends and no possibility to adapt the contract to the new conditions exists. Therefore, the case where performance becomes excessively difficult lies outside the scope of the technical term of impossibility. ${ }^{15}$

\footnotetext{
9 For some examples of these cases see, Yarg. HGK, 19.2.1997 T., E. 1996/11-674 K.1997/87; Yarg. HGK, 18.11.1988 T., E. 1998/13-815 K.1998/835; Yarg. HGK, 15.10.2003 T., E. 2003/13-599 K.2003/ 599; Yarg. HGK, 19.2.1997 T., E. 1996/11-762 K.1997/77; Yarg. HGK, 17.9.1997 T., E. 1997/11-460 K.1997/651.

10 Erzurumluoğlu, Op. Cit. p. 60.

11 Gürsoy, Op. Cit. p. 26.

12 Tunçomağ, Op. Cit. p. 887. According to Gürsoy, the important distinction is that if the debtor is incapable of performing, then this is a case of impossibility. However, if he/she is capable of performance but this performance cannot be expected of him/her, then this is a case where the principle of Clausula Rebus Sic Stantibus applies. Accordingly, the former is a natural and logical situation, where as the latter is a moral one. Gürsoy, Op. Cit. p. 27.

13 Akyol (2006, p. 86).

14 Erzurumluoğlu, Op. Cit. p. 61; Gürsoy Op. Cit. p. 27.

15 See Yarg. 13. HD, 16.4.1996 T., E.1996/3653 K.1996/3920. Similarly in another decision, the Court decided that non-delivery of some drugs because of a foreign-exchange bottleneck cannot be accepted as a technical impossibility which cancels the parties' obligations. For this decision see Yarg. 13. HD, 14.5.1981 T., E.1981/2749 K.1981/3786.
} 


\subsubsection{Economic impossibility in the Turkish draft code of obligations compared with the draft common frame of reference of the European Union}

In the current Turkish law, cases of economic impossibility are dealt with under the general doctrine of the collapse of the basis of transaction. However, in the reform draft of the Turkish Code of Obligations, prepared by the Ministry of Justice and submitted to the Turkish Grand National Assembly on December 24, 2007, the concept of excessive performance difficulty explicitly entered into Turkish law. Here is the text of the reform draft:

\section{"III. Excessive Performance Difficulty}

Article 137-If a condition, that at the time of the conclusion of the contract could not be foreseen by the parties and it cannot also be expected that the parties should have foreseen it, arises with a reason not originating from the debtor, and changes the facts present at the time of the conclusion of the contract, against the debtor in such a way that, demanding performance from him results against the principles of good faith, and if the debtor has not performed yet or he/she has performed by reserving his/her rights arising from the excessive difficulty of performance, the debtor has the right to demand from the judge adaptation of the contract to the new conditions, or if this is not possible, he/she has the right to avoid the contract. In long-term contracts, in principle, the debtor uses a right of termination rather than avoidance."

The issue of economic impossibility is also dealt with under the Draft Common Frame of Reference of the European Union (DCFR) ${ }^{16}$. However, there are some considerable differences between the two provisions on the same issue. First, DCFR differs from the Turkish solution in as far as it includes two symmetric cases of an excessive performance difficulty and an excessive reduction of the value of the contract for the other party. ${ }^{17}$ So, whereas in Turkish law these two cases are dealt

16 "III.-1:110: Variation or termination by court on a change of circumstances

(1) An obligation must be performed even if performance has become more onerous, whether because the cost of performance has increased or because the value of what is to be received in return has diminished.

(2) If, however, performance of a contractual obligation or of an obligation arising from a unilateral juridical act becomes so onerous because of an exceptional change of circumstances that it would be manifestly unjust to hold the debtor to the obligation a court may:

(a) vary the obligation in order to make it reasonable and equitable in the new circumstances; or

(b) terminate the obligation at a date and on terms to be determined by the court.

(3) Paragraph (2) applies only if:

(a) the change of circumstances occurred after the time when the obligation was incurred;

(b) the debtor did not at that time take into account, and could not reasonably be expected to have taken into account, the possibility or scale of that change of circumstances;

(c) the debtor did not assume, and cannot reasonably be regarded as having assumed, the risk of that change of circumstances; and

(d) the debtor has attempted, reasonably and in good faith, to achieve by negotiation a reasonable and equitable adjustment of the terms regulating the obligation."

17 Consider the following case: In 1960 a textile firm in the GDR (Former East Germany) bought machines of a type which were produced in 1930s from an exporter who ordered the machines from a still existing producer. The producer started producing them from the old blue prints. Before delivery a political crisis between west and east Germany made this business impossible and the buyer lost any interest in the contract (in economic terms his willingness to pay collapsed to zero after the contract 
within completely different areas of contract law leading to different tests, here we have one unified solution for both symmetric cases. The second difference is that according to the DCFR, the power of the court is very comprehensive, to the extent that the court can adjust the contract to the new circumstances or terminate the contract with no damages paid or with expectation damages or with reliance damages. Other solutions are also possible. Therefore one could argue that the DCFR gives more discretion to the courts than the Turkish solution which can lead only to a termination of the contract without any damage compensation or to an adjustment.

We will deal with the rationale and the consequences of the new rule of the Turkish Draft Code of Obligations from an economic perspective. This means that we will ask whether the proposed rules lead to an increase or a decrease of the economic wealth generated by contracts.

\subsection{Prevailing legal doctrines: a literature review}

The doctrine of impossibility deals with the following question: Which of the parties of a contract will bear the results of the impossibility of performance, within which limits? The prevailing doctrine answers this question in mainly two different ways. $^{18}$

The first group of writers approaches the question from the economic theory of efficient risk bearing and imposes the entire results of impossibility on either of the parties. Within this context Posner and Rosenfield argue that discharge claim can be brought in cases where the contract has not specifically allocated the risk of impossibility to either of the parties and the event, giving rise to the discharge claim was not avoidable by the promisor's any cost-justified precaution. According to the authors, if these two conditions have been satisfied, the loss should be placed on the party who is the superior (the lowest-cost) risk bearer. ${ }^{19}$ Similarly, Cooter and Ulen emphasize that efficiency requires allocating the risk to the party who can bear it at least cost. Therefore, an efficient impossibility doctrine should assign the liability to the party, which can bear the risk that performance becomes impossible, at least cost. ${ }^{20}$ Likewise, underlining that more attention should be paid mainly to the issue

\footnotetext{
Footnote 17 continued

formation). These particular machines were also not marketable outside the GDR. Under the DCFR it would be possible to entitle the buyer with a right not to accept the delivery and not to pay the price, but compensate the producer for the costs already incurred. Under the Turkish Draft Law this case would have to be decided on the basis of legal dogmas outside the scope of excessive performance difficulty.

18 Trimarchi, Op. Cit. p. 63. For an analysis of the doctrine of impracticability from a behavioural economics perspective also see Smythe, Op. Cit. p. 227.

19 The superior risk bearer can be figured by three factors: knowledge of the magnitude of the loss, knowledge of the probability that it will occur, and costs of self-insurance or market insurance. See Posner and Rosenfield (1977).

${ }^{20}$ Cooter and Ulen (2007, p. 241).
} 
of mitigation of damages, Bruce accepts the general economic approach taken by Posner and Rosenfield. ${ }^{21}$

Unlike the first group of writers who concentrate on figuring out the party that should bear the risk of impossibility, a second group of writers consider the issue of impossibility from the perspective of designing efficient remedies for breach of contract. They focus on dividing the risk of impossibility between the contracting parties, which results in a wide range of possibilities from expectation damages to no remedy. Accordingly, Shavell argues that when the parties to the contract are both risk-neutral, expectation damage induces efficient breach of the contract and also Pareto efficiency. However, if the parties' willingness and ability to bear risk differs, the allocation of risk enters into an evaluation of damage measures, and in such case reliance measure might be preferred. ${ }^{22}$ Accordingly, arguing that the "superior risk bearer" criterion is inappropriate and insurance is not an adequate option in such cases of absolute uncertainty, Trimarchi accepts that in a case of economic impossibility, efficiency might require that the contract is discharged or the price is adjusted. ${ }^{23}$ However, White argues that except for some very rare occasions, contracts should not be discharged, as a zero damage level leads to inefficiently high breach incentives on the performing party. ${ }^{24}$ On the other hand, according to Trakman, when a party claims that specific performance has become impracticable, rather than granting or denying an absolute excuse from nonperformance, the court should first of all focus on dividing the losses between the parties by considering each party's capacity to control the risk of loss arising from the non-performance. ${ }^{25}$

In order to show our stance, in the next sections, we will refer to the wealth generating function of contracts and discuss the choices of specific performance or damage compensation. We will also maintain under which circumstances, price adjustment or discharge of the obligation to perform is more appropriate.

\footnotetext{
21 See Bruce (1982).

22 Shavell (1980). Polinsky argues that the expectation and specific performance remedies can optimally allocate the contract risk only if one of the parties is risk neutral. Polinsky (1983). According to Eisenberg, if the parties shared a tacit incorrect assumption that the non-occurrence of some circumstance was certain, the promisor should only be liable for reliance damages. However, in cases where increase in prices and costs result in a loss to a promisor that is significantly greater than the risk the parties reasonably would have expected the promisor to have taken, the promisor should be liable for a modified form of expectation damages, but not full expectation damages. Eisenberg, Op. Cit. p. 207.

23 Trimarchi, Op. Cit. p. 81-82. According to Speidel, court-imposed price adjustments can be made in a some occasions, since the parties should share through compromise the unbargained for gains and losses. Additionally, the advantaged party has the duty to cooperate and bargain in good faith ex-post. Moreover, the adjustment of the court redresses the advantaged party's opportunistic conduct. Speidel (1981-1982).

24 White (1988). Skyes claims that although it is not always inefficient to discharge contractual obligations, the efficiency of discharge is exceptionally difficult to ascertain. According to the author, the information required to prove the necessity of discharge will rarely be available to the courts. Skyes, Op. Cit. p. 93 (1990).

25 Trakman (1984-1985). Also see Perloff (1981).
} 
1.3 Contracts as wealth generating mechanisms

\subsubsection{The allocation of risks in a fully specified contract}

We concentrate on contracts that are to the mutual benefit of the parties. ${ }^{26}$ For simplicity's sake, we refer to a "seller", who owes specific performance, and a "buyer".

Contracts shift scarce economic resources into the hands of those who value them the most. However, contracts also involve risks. Complex contracts with complex risks are typical of an advanced market economy and they involve in particular the risk of change of circumstances between contract formation and performance. $^{27}$

In a legal environment in which the law has not allocated some risk, for instance, a rise in raw material prices, the parties must then allocate the risk themselves in the pre-contractual negotiations. They shift the risk to the cheapest cost avoider, i.e., to the party, which can mitigate the damage from the risk, insure, or self-insure the risk at the lowest cost. ${ }^{28}$ This outcome is desirable from the point of view of the society, as all of us are interested in legal arrangements, which reduce the total costs of production and consequently reduce prices of goods and services. Nevertheless, this arrangement is also in the interest of the parties themselves because it increases the total surplus from the contract. Subsequently, the total gain from shifting risks to the cheapest cost avoider can be distributed among the parties.

\subsubsection{The rationale of default rules in contract law}

As Ronald Coase has shown in a celebrated article, ${ }^{29}$ parties will always find the efficient risk allocation in a contract if transactions costs are negligible. Yet, in most cases transactions costs are not zero. They might be so high that many risks remain unallocated by the parties. In such situations, the legal order helps the contracting parties by providing a set of default rules in the contract code.$^{30} \mathrm{It}$ is, however, important to note that the distribution of risks does not only affect the total surplus from the contract, but also the price of the goods or services. The more the law shifts risks to the buyer, the lower the price of the good or service will be, and vice versa.

\footnotetext{
${ }^{26}$ On contracts' wealth creating function see (Schäfer and Ott, The economic analysis of civil law, Unpublished Edited Version).

${ }^{27}$ See Speidel (2007), Wladis (1988), Barnett (2005, p. 407), Gillette (1990), Triantis (1992).

${ }^{28}$ See Coase (1960), See Calabresi (1970). See Posner and Rosenfield, Op. Cit. p. 90. On the importance of mitigation of losses also see Bruce, Op. Cit. 311.

${ }^{29}$ Coase, Op. Cit. p. 15.

${ }^{30}$ Schäfer (2006).
} 
1.4 The life of the contract if performance costs increase after contract formation

\subsubsection{The costs of performance increase but the contract still generates a net surplus}

After contract formation but before delivery, the cost of performance may rise in such a way that although the contract leads to a loss on the part of the seller, it still generates a surplus. At such circumstances, there is no reason from an economic point of view to terminate the contract. Because, the contract still increases the total wealth of the society. Its economic rationale to generate surplus is still intact. As a result the seller will incur additional costs arising from this increase. This is not unfair because the reservation price of the seller includes the expected costs to mitigate, insure or bear any cost increases after contract formation, given the efficient allocation of risk to the cheapest cost avoider. Moreover, it is economically efficient, because the contract still generates a net surplus.

To achieve this end, contract law provides the buyer with a remedy in case of breach. Accordingly he can insist on specific performance. If the seller disregards a court order to perform, this would be a contempt of court, a behaviour that can ripen into a criminal offense. If law enforcement is swift, the seller will perform because this makes him better off than not performing. This is the desired outcome from a legal policy point of view. Alternatively, the buyer can claim damage compensation in case of non-performance and get a damage payment. In that case, he does not pay the price and the seller has a total net loss which is higher than the loss he would incur in case of performance. Again, the seller is better off by performing than by not performing. In other words, the rule of specific performance and the rule of expectation damages both guarantee that specific performance makes the seller better off than a breach, as long as the contract produces a net surplus. This is the desired outcome from a legal economic point of view ${ }^{31}$.

\subsubsection{The costs of performance increase and specific performance would generate a negative surplus}

After contract formation, if the cost of performance increases in such a way that the loss of the seller is higher than the profit of the buyer upon specific performance, this shows that the increase in the cost of performance destroys the total surplus from the contract and makes it negative, as the contract produces a net loss or negative surplus. In other words, specific performance would destroy the economic rationale of the contract to produce a surplus.

Contract law should provide remedies that make parties better off when they do not deliver specific performance. Otherwise, the economy would waste resources. However, a doctrine of economic impossibility is neither necessary nor desirable to achieve this result. As we will show, the result of contract termination in this constellation is obtained with the rule of specific performance as well as with the

$\overline{{ }^{31} \text { See Trimarchi, Op. Cit. p. } 74 .}$ 
rule of expectation damages. In Anglo-Saxon countries, specific performance is usually not an option, but damage compensation is.

If the party that breaks the contract pays expectation damages, this is not only a fair result for the party suffering from the breach. ${ }^{32}$ It is also a mechanism, which ensures breach of contract if and only if this is efficient from the economic perspective. Under a rule of expectation damages, the seller is obliged to pay compensation without receiving the income. Therefore, if the costs increase in such a way that the cost of performance is less than the loss of income (which includes the damage compensation), the seller will not breach the contract and prefer to perform. This is efficient because the contract still generates a net surplus. If the cost increase was greater, and the loss of income including damage compensation (consisting of damages and the loss of the contractual price) was less than the cost of performance consequently, the seller would decide to break the contract. This is again an efficient result from an economic perspective. That way, we cannot have a party producing something at a cost for which even the highest valued buyer is willing to pay less than its cost.

Thus, the rule of expectation damages provides a mechanism, which gives incentives for the party that owes specific performance to breach a contract if and only the circumstances, which arise between the formation of the contract and performance, make the total surplus from the contract negative.

In legal practice, this rule has some severe shortcomings. The buyer receives his lost profits. If, however, the buyer also loses reputation vis-à-vis his customers, it is questionable whether these losses can be compensated. The plaintiff has to specify his damages and many damages are too vague to prove even though they exist. Even to merely prove loss of profit is often very time consuming and costly. Remember the case of the restaurant owner and his idea to open a "nostalgia restaurant". How can he convince the court that this was a very profitable idea and that the furniture was essential to realizing that profit? This is unlikely and he will probably be awarded only a small amount of damage compensation.

Furthermore, hardly any of the buyer surplus is recoverable. In many countries, for instance in Germany, the sentimental value that the buyer attaches to the good or service is not recoverable in court because it is so hard, if not impossible, to evaluate in money terms. For example, assume that somebody contracts to buy a valuable Eighteenth century carpet at a certain price. The loss of sentimental value in case of breach can be a large fraction or even multiple of the purchase price and is almost impossible to assess. Therefore, the rule of damage compensation for breach of contract is a perfect mechanism to strike down inefficient contracts if the courts are able to assess accurately the damage and have no tendency to over- or under compensates the losses. In legal practice, this rule will often lead to under compensation. As the breaching party knows such fact and will consider it when deciding whether to breach, some contracts will be breached even while the joint surplus remains positive. This is an inefficient and socially undesirable outcome.

The second rule is specific performance, according to which the buyer can force the seller to perform. If the seller fails to perform in defiance of the court order, this

$\overline{32}$ See Trimarchi, Op. Cit. p. 76. 
amounts to an obstruction of court, which can ripen into a criminal offence. Assume now for the argument's sake that the buyer can actually force the seller to perform even if the costs increase substantially and destroy the total surplus from the contract. In such a situation, so the argument goes, the parties would still terminate the contract, which is desirable from a social point of view.

The seller would then strike a new deal with the buyer, offering to compensate his losses plus some additional amount of money to get out of the contract. The buyer is then even better off than he would have been if the original contract had been performed. Therefore, the rule of specific performance will also lead to performance of the contract as long as the contract still produces a total surplus. It will produce a new contract to terminate the old contract at a price whenever specific performance would result in a negative surplus.

It is easy to see that under the expectation damages rule, the seller is in a stronger position than under the specific performance rule. Under specific performance, there are higher transfer payments from the party, who owes specific performance to the other party. In comparison to the rule of expectation damages, specific performance has the undeniable advantage that a contract is only terminated if the buyer agrees. He will do so only if all of his losses (and more) are compensated, including even those losses that he would not be able to prove under a rule of damage compensation or that are not legally recoverable. This precludes under compensation of the buyer when the contract is terminated.

This is the upside of the specific performance rule. The downside is that the law puts the buyer in a holdup position, in which he can extract much of the gain from the breach. To illustrate: In Germany, a car manufacturer sold a car with a particular catalytic converter. After contract formation but before delivery, the regulatory norms changed in accordance with EU regulation to a somewhat lower standard. The manufacturer delivered the car with a converter that met the new EU standard. The customer insisted on the converter that was stipulated in the contract. The company argued - in vain - that the contractual converter existed only as a blue print and to manufacture only a single piece would cost much more than to manufacture another car. Here the rule of specific performance guarantees that the buyer gets exactly what he wants if he values the promised converter very highly. This is a desired result. Otherwise, he can extract large sums of money from the car manufacturer to be released from the contract and let off the hook. This hold up position does not only redistribute wealth to some extent, which many would regard as unfair. It might also increase the costs of renegotiations, raise production costs and lead to an inefficient cross subsidisation from other customers to those who use their strong contractual position to extract rents.

Our conclusion is that in principle both remedies for breach of contract, expectation damages and specific performance, provide a mechanism to end the contract when performance becomes so costly that it would lead to a negative total surplus from the contract, and to honour the contract as long as it generates a positive total surplus. However, in practice damage compensation often leads to under compensation with the result that sellers also break some efficient contracts. In other words, the position of the buyer might be too weak. By contrast, the rule of specific performance guarantees that all efficient contracts are honoured, but that 
due to the hold up position and high transactions costs some inefficient contracts are also honoured. In other words, the position of the buyer might be too strong. The two rules provide good but not perfect mechanisms to separate efficient from inefficient contracts.

\subsection{Approaching economic impossibility}

\subsubsection{The case of contract termination}

The question now arises as to why we need a rule of economic impossibility if we have a mechanism, which reliably puts all inefficient contracts in one box and all efficient contracts into another, in the sense that inefficient contracts will not be performed, and efficient contracts will be performed. The rationale for the necessity of this rule is as follows:

Assume a case in which the costs of performance become excessively high and it becomes obvious for everybody that in this situation, specific performance would destroy all the gains from the contract and leave the performing party with an additional large loss.

In this case, it becomes obvious both for the parties and for any third party that specific performance would not only destroy the total surplus from the contract but would make it highly negative. Therefore, in this case it is not necessary to rely on costly mechanisms to induce the parties to decide whether a contract should be breached or performed. This is obvious for every outsider including a judge. In this case, a rule of economic impossibility would reduce transaction costs. This rule would entitle the seller to deny performance but would not entitle the buyer to damage compensation. An economically sound evaluation of the doctrine of economic impossibility would require answering three different questions.

First, was the increased cost of performance a low probability event? If it was not, such as an increase in the prices of raw materials, a change of interest rates, a change of the inflation rate, or a change of the exchange rate, the seller can take this into consideration when he forms his price. For instance, he may engage in forward contracting or demand a price that reflects the risk. The economic rationale to include a test of low probability or foreseeability is that high risk can be taken care of in the contract itself. Assume that at the time of contract formation the buyer has a willingness to pay 120 and the seller knows that dependent on circumstances his costs for the specific performance will be either 100 or 1,000 with an equal probability. Then his expected costs of the specific performance will be 550 and he will consequently not agree to the contract as long as the price is below 550. In that case there will be no contract. The alternative would be a clause stipulated in the contract, which allows the seller to deny the specific performance in case the high cost alternative realises. In that case, the price for the service or good will be higher than 100 and lower than 120. It can therefore be left for the parties either to allocate the risk of excessive performance difficulty to the buyer, or alternatively to abstain from the contract. A rule of economic impossibility imposed by the legal order makes therefore sense in those cases in which transactions cost are high and consequently the parties do not care about low probability risks. 
Second, was the increase of the costs of specific performance so high that performance would obviously cause a negative surplus? We have already pointed out that even without any rule of economic impossibility or base of the contract, the contract will be terminated in this case under a rule of expectation damages, as well as under a rule of specific performance. Expectation damages ideally guarantee that a contract will be breached if and only if the total surplus from the contract becomes negative. And under the rule of specific performance, parties have an incentive to end the contract by a new agreement when this is economically efficient. Both rules, however, have their disadvantages in practice and are costly in terms of transactions cost. Therefore, a rule of economic impossibility which allows denial of the specific performance is reasonable only in those cases in which it is clear for an outside observer that the value of a contract becomes negative. This saves transactions cost, for instance costly damage assessment.

Third, for this case group, it is therefore important not only to include the cost increase but also the interests of the buyer in the concept of economic impossibility. If the costs of performance increase so much that it is certain that the benefits from the contract would be destroyed by performance, the contract should be terminated under this doctrine. We regard it as a weakness of the Turkish Draft Law that it does not explicitly take the buyer's interest into consideration but concentrates on the specific performance difficulty as such. This is different from the DCFR but also from the solutions in other countries, for instance in Germany.

In Germany the legal doctrine of economic impossibility explicitly takes buyer surplus into account. This doctrine, which was originally judge made, became part of the civil code as part of a reform in 2002 (Schuldrechtsreform). In Subsection 275,2 , economic impossibility is contingent on an excessive increase in the costs of performance but also on the interest of the party, which is entitled to specific performance. This solution to the problem is in line with economic reasoning.

To illustrate the intuition behind the economic argument, consider the following example. A hospital buys from an importer medicine which is not easily available on the local market. For simplicity's sake, assume that there are only two types of medicine: one medicine which relieves a rare but relatively harmless type of acne, and insulin, which is a life saving medicine for a particular type of patients. Assume that the importer is contractually obliged to make a weekly delivery of medicine, which he imports from a foreign company, to the hospital at a fixed price. Assume now that a particular delivery becomes difficult because the production site of the company from which the importer receives the delivery burns down. To honour the contract and make a timely delivery, it would be necessary for the importer to rent a helicopter to get the acne medicine and insulin from two different foreign companies. This would imply an excessive increase in performance costs. A doctrine that incorporates the idea of a buyer surplus would lead to the conclusion that for the acne medicine contract this might be a case of economic impossibility leading to the termination of this week's specific performance. No patient suffers a serious harm if this disease is not treated for a week. But for insulin, it would be necessary for the importer to rent a helicopter for perhaps several thousand Turkish Liras per hour to provide the life saving medicine on time if no cheaper method exists. A seller of insulin must know at the time of contract formation how 
important the timely delivery is. Unlike a seller of a less important medicine, he must form a price that reflects even excessive risks. Even though the costs of delivering both medicines have risen equally high, our considerations would lead to economic impossibility and the right to deny the specific performance in the case of the acne medicine. Here the consumer surplus is relatively low and it is easy to see that performance would end up in a negative total surplus from the contract. However, in the second case, the buyer's interest is extremely high and even though the performance costs become excessive it is equally clear that due to their life saving characteristics there remains a surplus for the buyer.

Should in this case price be adjusted to the changed circumstances? In our view, this is also not a case of price adjustment. The risk that a life saving medicine cannot be delivered through the usual chains is not extra-ordinary and prudent parties would take this into account. This is therefore not a case of price adjustment, even though the costs of performance have excessively increased. The hospital would have insisted that the insulin be delivered each week at whatever cost and it would have been willing to pay the price, which fully reflects this risk for the importer. However, again in a fully specified contract, the same clause would not have entered into the contract for the acne medicine, which is rare but does not have the same utility (consumer surplus).

Therefore, from an economic perspective, it is important to include in the concept of economic impossibility not only the unexpected and excessive changes of performance cost but also the interest of the other party in the contract (the buyer surplus). It is not the excessive and low probability increase of performance costs per se that triggers the right to deny specific performance but rather the increase in relation to the interest of the buyer (consumer surplus).

We therefore recommend that the Turkish reform proposal should explicitly take the interest of the other contracting party into consideration. This would be possible by adding a sentence to Article 137 of the Turkish draft proposal. "In making a decision on terminating the contract, the judge takes into consideration the party's interest in specific performance." One could argue that this is not necessary as the draft code makes reference to the good faith principle. ${ }^{33}$ The judges could make use of good faith in differentiating between the two sub-categories of a high and a low buyer's surplus. It is, however, questionable whether every judge understands the crucial importance of the interest for the decision to terminate the contract. The present wording of the draft code, which concentrates exclusively on increased costs of performance, does not provide him with any indication.

\subsubsection{The case of preserving the contract and increasing the price}

There is a second group of cases, in which the judge should not terminate the contract but increase the price of the good or service. For instance, if due to an unexpected and excessive difficulty of performance, the cost of performance

\footnotetext{
33 The wording of the Article is as follows: "If a condition... arises... and changes the facts present at the time of the conclusion of the contract, against the debtor in such a way that, demanding performance from him results against the principles of good faith..."
} 
increases considerably, but this cost is still less than the buyer's surplus (which was ex-ante significantly higher than the price), the contract should not be terminated as it still produces a net total surplus. But in this case, although there is a positive surplus from the contract, the contractual price is very low when compared to the actual costs of performance and the buyer's surplus. Therefore, the judge should increase the price of the good or service.

If the parties stipulated a fixed price, the contractual risks are usually allocated to the cheapest cost avoider either by the parties themselves or by law. ${ }^{34}$ Especially the risk of a cost increase after contract formation is shifted to the party which owes specific performance and the price of the good or service reflects the risk allocation. Therefore, this constellation should lead judges to order neither a termination of the contract nor a change of the stipulated price. However, economic considerations suggest two exceptions to this rule.

First: The risk, which led to an excessive rise of performance costs, was so remote that even the best-informed observer would not consider it. This condition is stricter than "unforeseeability". It is so improbable that not even Sherlock Holms would be able to consider this risk and would not think of adjusting the price stipulated in the contract accordingly. In such a case, when it is obvious that the price does not reflect the risk and if the contract still generates a surplus, the court should increase the price of performance. This is a rare case. In our introductory remarks we referred to a freight contract for freight to be shipped from Istanbul to Mumbai. The costs of shipping became excessively high because of the war between Israel and Egypt in 1973, which led to a closing of the Suez Canal. Consequently, the ships had to take their route around Africa. ${ }^{35}$ This contingency is so remote that even very diligent parties do not include it in the contract and it is therefore not reflected in the price. The contract can, however, still produce a surplus and therefore should not be terminated. In that case the judge should adjust the price to the increased cost of performance. We think, however, that in such cases the party who receives specific performance should have a right to opt out of the contract. To see why this is necessary, we divide the shipping case into two different sub-categories.

First, assume that the freight is coal and that the increased freight costs would make shipping unprofitable as well as economically inefficient. Under such circumstances, it would be better for Indian importers to buy their coal from other sources. If therefore the adjustment in price would make the contract unprofitable for the exporter of coal, he should be entitled to opt out of the contract. Second, if the freight is cameras, and therefore the value of one ton of cargo is very high, the contract may remain profitable from the buyer's perspective despite the excessive increase in transportation costs. In that case, the price adjustment as well as the validity of the contract is the economically and legally appropriate solution.

The draft law of the Turkish Code of Obligations has not explicitly allowed for this possibility. We therefore suggest that the draft code should explicitly include

\footnotetext{
${ }^{34}$ See above section $\mathrm{C} / 2$.

${ }^{35}$ See Posner and Rosenfield, Op. Cit. p. 103; See Trimarchi, Op. Cit. p. 81; Schlegel (1986-1969), Birmingham (1968-1969).
} 
this possibility and tentatively propose the following wording: "After the judge has set a new price for the specific performance, the other party is entitled to terminate the contract."

Second: The risk was foreseeable, but it is clear for an outside observer (the judge) that both parties have not considered it in the price formation. The consequence may be a gross imbalance of the gains from the contract. This sometimes happens in long term contracts, in which parties might foresee the effects of creeping inflation but are unable to appreciate the powerful exponential long run effects of small annual changes. This effect is particularly strong in long term contracts spanning 40 or 50 years, which often fail to take inflation risk properly into consideration. Even though creeping inflation is a widespread and well-known phenomenon in all Western countries and is therefore foreseeable, the terms of the contract often reveal beyond doubt that parties did not consider the inflation risk. In 1930s Germany, many land lease contracts stretched across a period of 50 years. When the rental contract was formed, the price reflected the market value of the land and it included some mark-up for inflation. However, 30 years later, the rental payments were often less than $10 \%$ of the market price. This made it obvious that inflation risk was not considered even though it was foreseeable. This is again a case, in which judges should adjust the price. Even though the risk was foreseeable, the contractual price clearly does not reflect the risk.

Article 137 of the Turkish Reform draft fully covers these two cases and it is therefore fully in line with economic considerations.

\subsubsection{The party, which owes the specific performance, negligently caused the excessive performance difficulty}

It is obvious from an economic perspective that the legal consequences, which we discussed so far do not apply if the "seller" has negligently caused the economic impossibility. ${ }^{36}$ If the consequence of his negligent behaviour is to make performance of the contract meaningless, the seller should be entitled to deny specific performance but the buyer should be entitled to claim damage compensation. Otherwise the seller's incentives to perform will be insufficient. If, however, the contract is still of great interest and still produces a surplus, the judge should not adjust the price to the new cost of performance. This again would give the seller an incentive to invest enough resources into the contract.

We propose to include the following rule into Article 137 of the reform draft. "If the party which owes specific performance has negligently caused the conditions which lead to termination of the contract, it must pay expectation damages. If the judge decides not to terminate the contract, he shall not adjust the price for the specific performance."

\footnotetext{
${ }^{36}$ Posner and Rosenfield also argue that the discharge of the contract should not be allowed when the event rendering performance uneconomical was reasonably preventable by either party. Posner and Rosenfield, Op. Cit. p. 98.
} 


\subsubsection{The exceptional character of a rule of economic impossibility}

A rule of economic impossibility gives more discretionary power to judges. It explicitly entitles them to terminate contracts or to adjust the price of specific performance even though parties stipulated a fixed price in the contract. It is therefore important to repeat that this rule of economic impossibility or impracticability is neither designed nor used around the world to reallocate contractual risks after contract formation. Usually parties themselves or the rules of contract law as they are found in the code have taken these decisions. It is not for judges to rewrite contracts ${ }^{37}$. As a rule that covers specific cases, economic impossibility helps the business community and consumers to keep transactions costs low. It is certainly not intended to insure businesspersons against risky activities. It is therefore a rule, which should be used with a high level of caution and restraint and only when it is obvious for everybody that in a situation, specific performance would not only destroy the total surplus from the contract but also would make it highly negative. Hence this condition brings an almost objective limit to the discretion of the judge and prevents any criticisms that due to the lack of expertise of judges, inappropriate decisions might be executed.

Faust and Huber recently proposed to curb judicial discretion in Germany in cases of economic impossibility. They suggest that the party, which owes the specific performance, should be entitled to deny performance (without damage payment), if the costs of the specific performance rise by an amount which exceeds the originally expected profit plus twice the interest of the other party in the performance. ${ }^{38}$ It is clear what the advantages and disadvantages of such a precise rule are. It provides more legal certainty. But it also leads to less flexibility for judges. Sometimes a lack of flexibility can badly backfire and can force judges to take absurd decisions. In this article we remain silent as to the question whether for the Turkish Code of Obligations such a clear rule with little discretion for judges or the relatively vague standard of the draft might be preferable. The Turkish draft is in line with the practice in Europe and the USA. Also, the reform process is much too advanced in Turkey as to discuss in detail the relative merits and shortcomings of a completely alternative approach to the problem.

Finally we deal with a more general and fundamental critique of the concept of economic impossibility ${ }^{39}$ and more general of contract law rules, for instance "good faith", which give courts ample discretion to add implicit and even change explicit terms of the contract. This critique is widespread especially in Britain, where even the good faith principle is rejected on the ground that it contradicts the commercial purpose and nature of the contract. It is widespread in other Common Law countries as well. According to this view courts should just interpret the contract as it is stipulated and should not substantially add or change anything but stick to what the

\footnotetext{
37 Goldberg (2007, p. 347).

38 Faust and Huber (2002, p. 50).

39 Here we refer to a suggestion of one of the referees, who maintains, that in principle all contingencies can be written into the contract, for instance in the case of the blockade of the suez canal or the live saving medicine. It is perhaps possible to include even very low probability events into the contract and allocate the risk accordingly to the cheapest cost avoider, but at a high cost.
} 
parties themselves have expressed. We disagree with this philosophy, even though we strongly support the basic concept of private autonomy inherent in the very idea of the contract, which gives rise to this critique. If courts are denied the possibility to correct a contract, this incentivises parties to stipulate all possible and impossible contingencies and write long copied and pasted laundry lists into the contracts. This often makes the contract so long, complicated and non-transparent that nobody, including the lawyers themselves understands it anymore. Typically in the Anglo Saxon world contracts are much longer and less transparent than on the European continent, ${ }^{40}$ where parties often refer to the good faith principle or other general clauses. They know that these legal concepts are only a short hand writing for long strings of legal decisions, which aim at increasing the ex ante efficiency of the contract. They also know, that a highly professional court will not try to redistribute wealth by way of contract law but to find a rule, which the parties would most probably have found, had they taken this risk into account. On the European continent parties are more inclined to accept far reaching court decisions in contract law as part of a service provided to them by the judiciary and the Supreme courts. This allows them to economise on the costs of contract formation and concentrate on the most important issues. It is true, however, that the use of such general clauses requires a judiciary, which in a hard case tries to find out what fair and self interested parties would have stipulated, had they taken care of the risk at the time of contract formation. General clauses can backfire if the judiciary tries to redistribute wealth or adjudicate politics or morals instead. However, the rise of general clauses in contract law in many countries of the world, show that their function, to keep the stipulated contracts cheap, transparent and short and provide parties with a valuable service is more and more appreciated.

\subsubsection{Dealing with Turkish critique of economic impossibility}

We fully agree with the observation that "economic impossibility" is a contradiction in terms. In addition, the term becomes completely meaningless when it covers both sub-categories of the problem under consideration. Remember that in the first sub-category, the judge terminates the contract because it is obvious that due to the excessive performance difficulties the contract cannot serve any reasonable purpose. The second sub-category, however, leads to an adjustment of price without necessarily terminating the contract. It still makes sense to speak of economic impossibility as a façon de parler if one considers only the first sub-category in which the judge terminates the contract because in this case the legal consequence of economic impossibility is the same as under impossibility. We call this economic impossibility in the narrow sense. The second category, however, in which the terms of the contract are adjusted but the contract remains valid, implies a legal consequence which has nothing to do with the impossibility doctrine. In some countries, like for instance Germany, legal dogma separates these two cases and the first case is labelled "economic impossibility", (section 275,II BGB) whereas the

\footnotetext{
${ }^{40}$ Hamburg based lawyers like to tell an anecdote, according to which a contract in Germany is written on 3 pages, in England on 30 pages and in the USA on 300 pages.
} 
second case is labelled "basis of the contract" (section 313 BGB). These are two separate concepts. The reform draft of the Turkish Code of Obligations, however, contains either one rule, which might lead to a termination of the contract (economic impossibility) or another rule which might lead to an adjustment of price (basis of the contract). As the Turkish law reform draft unifies these two cases, we agree that the term that applies to both categories should not be "economic impossibility".

Let us come back to our three illustrative cases of the Turkish Supreme Court (Yargitay). We think it was the right decision that the Turkish Court rejected the claim from a retirement income contract. In our view, this risk is foreseeable in a country like Turkey in which large fluctuations of the inflation rate and of the exchange rate have occurred several times in the past. For the same reason, we think that the contracts in case 1 and case 2 are valid. ${ }^{41}$

\section{Conclusion}

The Turkish Code of Obligations so far does not include an explicit norm for such contractual cases in which after the formation of the contract and before the specific performance, the costs of performance rise excessively. These cases are usually headed under doctrines such as commercial impracticability, economic impossibility or basis of the contract. Turkish law so far deals with these cases under the broad and unspecific cover of good faith and Clausula Rebus Sic Stantibus. However, the new reform proposal explicitly includes the possibility that a judge either terminates the contract or adjusts the price of a contract above the stipulated price.

We discuss this reform proposal regarding the Turkish Code of Obligations from a law and economics perspective. From this point of view, a contract is an instrument to increase the wealth of a nation. Fair contracts generate producer and consumer surplus. They shift resources into the hands of those, who value them most. A contract serves its economic purpose as long as it produces a surplus and is therefore wealth generating. It loses its very rationale, when circumstances arise which make this surplus negative. We therefore argue that whenever circumstances, which arise between contract formation and performance destroy the surplus from a contract or turn it into a loss, the contract should be terminated.

Usually, the rules of specific performance as well as the rule of damage compensation provide a mechanism to induce parties to honour a contract as long as the contract generates a surplus and to terminate the contract otherwise. However, certain circumstances exist in which parties save transactions costs when the contract is terminated under a rule of impracticability or of economic impossibility that is, without damage payments or in which the judge adjusts the price for the specific performance. The introduction of such a rule can either preserve the wealth generating character of a contract, or alternatively, it can terminate the contract, if it is obvious not only for the parties themselves but also for third parties (judges) that specific performance would lead to a mere waste of economic resources.

41 See above p. 4. 
We agree with most of the rules and the solutions found in the new proposal. However, economic considerations lead us to propose some changes to the draft. First, we propose that when terminating a contract a judge should take the interest of the party, which expects the specific performance, explicitly into account. Second, we propose that the damage claim should persist if the party, which owes the specific performance, has negligently caused the excessive performance difficulty. Third, we propose that in case the judge adjusts the price of the specific performance, the party, which has to pay this increased price, should be entitled to terminate the contract. We propose a combination of three tests to check whether a contract should be terminated or adjusted by the court.

From a systematic and economic point of view, it would be advisable to regulate the cases of an excessive performance difficulty and an excessive reduction of the interest of the other party in the contract with the same legal norm and with the same tests. The excessive reduction of the interest in the contract is fully symmetric to the excessive performance difficulty and should therefore be regulated by the same set of rules. Therefore we maintain that the DCFR is an improvement over what can be found in many legal orders including German Law or the Turkish Draft Proposal. Overall, we maintain that this reform proposal is an important step towards improving Turkish contract law, especially for the business community

\section{References}

Akyol, Ş. (2006). Dürüstlük Kuralı ve Hakkın Kötüye Kullanılması Yasağ (2nd ed.). İstanbul: Vedat.

Barnett, R. E. (2005). Perspectives on contract law (3rd ed.). New York: Aspen Publishers.

Birmingham, R. L. (1968-1969). A second look at the Suez Canal cases: Excuse for nonperformance of contractual obligations in the light of economic theory. Hastings Law Review, 20, 1393-1416.

Bruce, C. J. (1982). An economic analysis of the impossibility doctrine. Journal of Legal Studies, 11, 311-322.

Calabresi, G. (1970). The costs of accidents: A legal and economic analysis (1st ed.). New Haven: Yale University Press.

Coase, R. (1960). The problem of social cost. Journal of Law and Economics, 3, 1-44.

Cooter, R., \& Ulen, T. (2007). Law and economics (5th ed.). Reading: Addison Wesley.

Eisenberg, M. A. (2009). Impossibility, impracticability, and frustration. Journal of Legal Analysis, 1, 207-261.

Eren, F. (2008). Borçlar Hukuku Genel Hükümler (9th ed.). İstanbul: Beta.

Erzurumluoğlu, E. (1970). Türk-Isviçre Borçlar Hukuku Sistemine Göre Borçluya Yüklenemeyen Nedenlerden Dolayl Edimin Yerine Getirilememesi (1st ed.). Ankara: İktisadi ve İdari İlimler Akademisi.

Faust, F., \& Huber, P. (2002). Schuldrechtsmodernisierung - Einführung in das neue Recht. München: Verlag C.H. Beck.

Gillette, C. P. (1990). Commercial relationships and the selection of default rules for remote risks. Journal of Legal Studies, 19, 535-582.

Goldberg, V. P. (2007). Framing contract law: An economic perspective. USA: Harvard University Press.

Gürsoy, K. T. (1950). Hususi Hukukda Clausula Rebus Sic Sitantibus (Emprevizyon Nazariyesi) (1st ed.). Ankara: Ankara Üniversitesi.

Kaplan, İ. (2007). Hakimin Sözleşmeye Müdahalesi (2nd ed.). Ankara: Seçkin.

Perloff, J. M. (1981). The effects of breaches of forward contracts due to unanticipated price changes. Journal of Legal Studies, 10, 39-64.

Polinsky, A. M. (1983). Risk sharing through breach of contract remedies. Journal of Legal Studies, 12, 427-444. 
Posner, R. A., \& Rosenfield, A. M. (1977). Impossibility and related doctrines in contract law: An economic analysis. Journal of Legal Studies, 6, 83-118.

Schäfer, H. B. (2006). Precise legal norms as substitutes for human capital in low-income countries. Supreme Court Economic Review, 14, 113-134.

Schlegel, J. H. (1986-1969). Of nuts, and ships, and sealing wax, suez, and frustrating things-the doctrine of impossibility of performance. Rutgers Law Review, 23, 419-448.

Serozan, R. (2006). Borçlar Hukuku Genel Bölüm (4th ed.). İstanbul: Filiz.

Shavell, S. (1980). Damage measures for breach of contract. The Bell Journal of Economics, 11, 466-490.

Skyes, A. (1990). The doctrine of commercial impracticability in a second best world. Journal of Legal Studies, 19, 43-94.

Smythe, D. J. (2003-2004). Bounded rationality, the doctrine of impracticability, and the governance of relational contracts. Southern California Interdisciplinary Law Journal, 13, 227-268.

Speidel, R. E. (1981-1982). Court-imposed price adjustments under long-term supply contracts. Northwestern University Law Review, 76, 369-422.

Speidel, R. E. (2007). Contracts in crises: Excuse doctrine and retrospective government acts (1st ed.). Durham: Carolina Academic Press.

Trakman, L. E. (1984-1985). Winner take some: Loss sharing and commercial impracticability. Minnesota Law Review, 69, 471-519.

Triantis, G. G. (1992). Contractual allocations of unknown risks: A critique of the doctrine of commercial impracticability. University of Toronto Law Journal, 42, 450-483.

Trimarchi, P. (1991). Commercial impracticability in contract law: An economic analysis. International Review of Law and Economics, 11, 63-82.

Tunçomağ, K. (1967). Alman Hukukunda Borcun İfasında Aşırı Güçlük (Muamelenin Temeli) ile İlgili Görüşler. Ístanbul Üniversitesi Hukuk Fakültesi Dergisi, 32, 887-987.

White, M. J. (1988). Contract breach and contract discharge due to impossibility: A unified theory. Journal of Legal Studies, 17, 353-376.

Wladis, J. D. (1988). Impracticability as risk allocation: The effect of changed circumstances upon contract obligations for the sale of goods. Georgia Law Review, 22, 503-666. 